\title{
ANALISIS FEMINISME RADIKAL TOKOH FIRDAUS DALAM NOVEL PEREMPUAN DI TITIK NOL KARYA NAWAL EL SAADAWI
}

\author{
$\operatorname{Maziah}^{1}$, Sumiharti $^{2}$, Erlina Zahar $^{3}$ \\ Jambi \\ Maziahjafar@11yahoo.com \\ Harti_Sumi@yahoo.com \\ Erlina_zahar@yahoo.com
}

Program Studi Pendidikan Bahasa dan Sastra Indonesia, Fakultas Keguruan dan Ilmu Pendidikan, Universitas Batanghari,

\begin{abstract}
The purpose of this research is to describe the radical feniminism in the main character in the novel Perempuan Di Titik Nol by Nawal El-Saadawi which refers to three aspects, they are: (1) violence against woman, (2) woman's exploitation, and (3) role of woman. This research is descriptive qualitative. The data is taken from the characters' utterances and from the story which represents radical feminism aspects. The data are analyzed by using structural approach. Based on the result, it is found that radical feminism in the main character in the novel Perempuan Di Titik Nol karya Nawal el-Saadawi refers to these three aspects, they are: (1) 15 utterances refer to violence against woman, (2) 8 utterances refer to woman exploitation (3) 9 utterances refer to the role of woman, which is supported by the dialog or utterances in the novel.
\end{abstract}

Key Words: radical feminism, character, novel Perempuan di Titik Nol

\footnotetext{
${ }^{1}$ Mahasiswa Program Studi Pendidikan Bahasa dan Sastra Indonesia, Fakultas Keguruan dan Ilmu Pendidikan, Universitas Batanghari, Jambi

${ }^{2}$ Dosen Program Studi Pendidikan Bahasa dan Sastra Indonesia, Fakultas Keguruan dan Ilmu Pendidikan, Universitas Batanghari, Jambi

${ }^{3}$ Dosen Program Studi Pendidikan Bahasa dan Sastra Indonesia, Fakultas Keguruan dan Ilmu Pendidikan, Universitas Batanghari, Jambi
}

Analisis Feminisme Radikal Tokoh Firdaus dalam Novel Perempuan Di Titik Nol Karya Nawal El Saadawi 


\section{PENDAHULUAN}

Karya sastra yang diciptakan oleh pengarang merupakan hasil kreativitasnya. Karya sastra tersebut dihasilkan melalui pengamatan terhadap lingkungan sosial dan masyarakat, ataupun melalui pengalaman hidup pengarang, masalah pribadi atau masalah kehidupan yang dialamiya sehingga memunculkan ide-ide kreatif yang dituangkan melalui sebuah tulisan dalam bentuk karya sastra. Hal tersebut sesuai dengan pendapat Semi (dalam Siswantoro, 2008:67) menyatakan bahwa "Sastra lahir oleh dorongan manusia untuk mengungkapkan diri, tentang masalah manusia, dan semesta". Berdasarkan penjelasan di atas, dapat disimpulkan bahwa karya sastra sebagai hasil kreatif yang objeknya adalah manusia dan kehidupan deengan menggunakan bahasa sebagai medianya. Sastra berarti segala tulisan atau karangan yang mengandung nilai-nilai kebaikan yang ditulis dengan bahasa yang indah. Adapun jenis karya sastra yang menarik untuk dibaca adalah novel, novel mengandung nilai-nilai kehidupan serta ajaran untuk kehidupan manusia, mengubah cara berpikir manusia terhadap suatu fenomena kehidupan serta dapat menimbulkan semangat juang dalam mencapai cita-cita. Novel merupakan cerita berbentuk prosa yang menyajikan permasalahan-permasalahan secara kompleks dengan penggarapan unsurunsurnya secara lebih luas dan rinci pada tokoh. Watak tokohpun lebih berkembang sampai mengalami perubahan nasib. Penokohan pada akhirnya menggambarkan karakter. Hal ini sesuai dengan pendapat Sumiharti dalam jurnalnya yang berjudul Moral values of trilogi novel Jendelajendela Pintu, And Atap By Fira Basuki "Human getting complex characterised by a appearance of various problems and global issues. Global isuess can be a violation of the human rights, the phenomenom of violence, murder, drugs, fighting between students and domestic violence. Global issues can minimise by knowledge of moral. Of its consequnces is different the development of the situation and condition community, as lameness and gap sosial, injustice, and the from of other social norm deviations still often foud everywhere". ("Penokohan dapat menggambarkan karakter manusia yang menjadi kompleks dan ditandai dengan munculnya berbagai masalah global. Isuisu global dapat menjadi pelanggaran hak asasi manusia, fenomena kekerasan, pembunuhan, narkoba, pertikaian, antara murid-murid dan kekerasan dalam rumah tangga. Perkembangan situasi dan dan kondisi masyarakat dapat mengakibatkan terjadinya kesenjangan sosial, ketidakadilan, dan dari penyimpangan norma sosial lainnya yang sering terjadi dimana-mana") Penggambaran latar lebih detail. Bersamaan dengan perjalanan waktu terjadi perubahan-perubahan hingga komplik terselesaikan.

Novel Perempuan Di Titik Nol karya Nawal el-Saadawi ini pertama dicetak Agustus 1989, dengan jumlah halaman 176 halaman. Novel ini berbeda dari novel-novel Nawal el-Saadawi sebelumnya. Karena tidak mengandung nilai feminisme yang begitu kental, topik kali ini adalah perempuan, yang merupakan makhluk yang dianggap lemah dan diperlakukan secara tidak adil oleh laki-laki dan berbagai tindakan kekerasan seksual yang dia terima. Dengan kekerasan seksual yang ia dapatkan ini lah dia mencoba untuk bangkit dari kesengsaraan yang dia rasakan sehingga melakukan perlawanan dalam bentuk tindakan.

Feminisme radikal ini mempermasalahkan antara lain tubuh serta 
hak-hak reproduksi, seksualitas, relasi kuasa perempuan dan laki-laki. Novel ini juga menggambarkan kurangnya informasi tentang seks yang akhirnya merugikan pihak perempuan. Seperti pelecehan terhadap tubuh, dan aturan-aturan yang boleh dilakukan laki-laki tetapi tidak boleh dilakukan perempuan. Peran agama dalam novel Perempuan di Titik Nol juga tidak memberikan solusi atas ketimpangan dan kekerasan gender yang dialami perempuan. Hal ini dapat dilihat dari pengarang yang menggambarkan bahwa laki-laki yang suka beribadahpun tetap memandang perempuan sebagai makhluk yang rendah, bahkan agama dijadikan kepentingan tertentu oleh kaum laki-laki.

Novel Perempuan di Titik Nol karya Nawal el-Saadawi ini perlu diteliti karena novel ini mengandung unsur feminisme. Feminisme terbagi ke dalam beberapa jenis, yaitu feminisme lberal, feminisme radikal, feminisme postmodern, feminisme anarkis, feminisme marxis, dan feminisme sosialis, serta feminsme postkolonial. Penelitian ini hanya berfokus pada femisme radikal. Adapun beberapa penelitian yang relevan dengan penelitian ini adalah sebagai berikut. Pertama, penelitian yang dilakukan oleh Agus Setiawan Prestiono mahasiswa Fakultas Sastra Universitas Jember dalam skripsi yang berjudul "Analisis Feminisme Radikal dalam novel Wajah Sebuah Vagina Karya Naning Pranoto: Suatu Tinjauan Ketidakadilan Gender. Penelitian ini dilakukan pada tahun 2013. Kedua, penelitian yang dilakukan oleh Yulianda Pertiwi mahasiswa Jurusan Bahasa dan Sastra Malang. Dalam skripsi yang berjudul "Representase Feminisme Radikal Pada Tokoh Aoname dalam Novel 1Q84 karya Murakami Haruki: Suatu Tinjauan Ketidakadilan Gender. Penelitian ini dilakukan pada tahun 2015. Ketiga, penelitian yang dilakukan oleh Masriah mahasiswa Jurusan Pendidikan Bahasa dan sastra Indonesia Fakultas Bahasa dan Seni Universitas Negeri Jakarta yang berjudul "Sikap Radikal Tokoh Perempuan dalam Si Parasit Lajang Karya Ayu Utami: Suatu Tinjauan Sastra Feminis. Penelitian ini dilakukan pada tahun 2015. Keempat, penelitian yang dilakukan oleh Mardiana mahasiswa Jurusan Pendidikan Bahasa dan Satra Indonesia Fakultas Keguruan dan Ilmu Pendidkan Universitas Maritim Raja Ali Haji Tanjung Pinang, yang berjudul "Feminisme Radikal Dalam Kumpulan Cerpen1874 Karya Tamara Geraldine dan Kawan-Kawan: Suatu Tinjauan Sastra Feminis. Penelitian ini dilakukan pada tahun 2016.

Keempat penelitian tersebut relevan dengan penelitian ini karena samasama menganalisis feminisme radikal. Perbedaannya terletak pada objek penelitiannya sehingga feminisme radikal yang dikajipun berbeda.

Berdasarkan latar belakang di atas, penulis memfokuskan penelitian ini pada feminisme radikal tokoh Firdaus dalam novel Perempuan di Titik Nol karya Nawal el-Saadawi dilihat dari bentuk kekerasan terhadap perempuan, eksploitasi perempuan, dan peran perempuan. Adapun pertanyaan dalam penelitian ini adalah bagaimana feminisme radikal tokoh Firdaus dalam novel Perempuan Di Titik Nol?

\section{METODE PENELITIAN}

Jenis penelitian ini adalah deskriptif kualitatif. Penelitian deskriptif ini dapat diartikkan sebagai prosedur pemecahan masalah yang diselidiki dengan menggambarkan atau melukiskan keadaan subjek dan objek. Penelitian pada saat sekarang berdasarkan fakta-fakta yang tampak atau sebagaimana adanya" (Nawawi dalam Siswantoro, 1987:56).

Penelitian ini digunakan untuk mendeskripsikan gejala, kejadian yang 
terjadi dalam suatu penelitian agar diperoleh pembahasan lebih dalam mengenai feminisme radikal tokoh Firdaus yang terdapat dalam novel Perempuan $D i$ Titik Nol karya Nawal el-Sadaawi. Menurut Dezin (dalam Moleong, 2010:5) "Penelitian kualitatif adalah penelitian yang menggunakan latar alamiah dengan maksud menafsirkan fenomena yang terjadi dan dilakukan dengan jalan melibatkan berbagai metode penelitian".

Teknik pengumpulan data yang dilakukan dalam peelitin ini beberapa langkah di antaranya adalah sebagai berikut (Rafiek, 2012: 76).

Pertama, membaca keleluruhan novel terlebih dahulu, dari pembacaan ini, diperoleh pengetahuan dan kesan tentang cerita tokoh-tokohnya, serta berbagai peristiwa yang mereka alami. Kedua, apabila cerita-cerita itu terlalu panjang, maka cerita tersebut dapat dibagi menjadi beberapa episode. Apabila cerita dibagi menjadi beberapa episode, maka perlu pembacaan ulang terhadap cerita-cerita tersebut dengan lebih seksama untuk memperoleh gambaran tentang episode serta memperoleh pengetahuan yang jelas, yang dapat digunakan sebagai dasar dalam analisis ini. Ketiga, setiap episode mangandung deskripsi tentang tindakan atau peristiwa (mytheme atau cerytheme) yang dialami tokoh-tokoh dalam cerita. Keempat, memperhatikan adanya suatu relasi, kalimat-kalimat yang menunjukkan hubungan tertentu antarelemen dalam suatu cerita. Kelima, cerita-cerita disusun secara diakronis, atau mengikuti sumbu sintagmatik dan padigmatisnya dengan elemen-elemen lain. Keenam, mencoba menarik relasi antar elemen-elemen di dalam suatu cerita secara keseluruhan. Langkah ini dimaksudkan untuk mengontrak sebuah makna cerita secara internal yang dapat disimpulkan sebagai suatu bangunan makna. Ketujuh, menarik kesimpulan akhir dengan mencoba memaknakan cerita-cerita internal dengan kesimpulan-kesimpulan referensial atau kontektual dimana cerita itu berada dan mencoba menarik sebuah makna umum yang menempatkan makna internal itu sebagai bagian dari makna-makna umum secara internal.

Data dalam penelitian ini berupa data yang berwujud kalimat-kalimat dialog antar tokoh yang memiliki makna yang mengandung aspek-aspek feminisme radikal tokoh Firdaus dalam novel Perempuan di Titik Nol karya Nawal elSaadawi.

Menurut Arikunto (2010:172) "Yang dimaksud dengan sumber data dalam penelitian adalah subjek data yang diperoleh". Sumber data dalam penelitian ini adalah novel. "Perempaun Di Titik Nol karya Nawal el-Saadawi cetakan Agustus 1989.

"Menganalisis data berubah menjadi data yang mentah menjadi data yang mempunyai makna dan mengarah kepada kesimpulan" (Arikunto, 2010:53). Data dianalisis dengan menggunkakan langkah-langkah sebagai berikut. Pertama, setelah semua data terkumpul, kemudian dilakukan pengecekan dan pegelompokkan data sesuai tabel tabulasi. Kedua, mendeskripsikan data berdasarkan tokoh Firdaus sesuai aspek yang diteliti. Ketiga, menganalisis novel, dengan mencari tokoh Firdaus dengan melihat aspek feminisme radikal. Keempat, membuat tabel analisis feminisme radikal tokoh Firdaus. Kelima, menarik kesimpulan.

\section{HASIL DAN PEMBAHASAN}

Berdasarkan analisis data yang telah dilakukan, hasil yang didapatkan bahwa 
aspek-aspek feminisme yang terkandung dalam novel Perempuan Di Titik Nol karya Nawal el-Saadawi terdiri atas: kekerasan terhadap perempuan; ekploitasi perempuan; dan peran perempuan.

Kekerasan terhadap perempuan merupakan salah satu aspek feminisme radikal yang terdapat dalam novel Perempuan Di Titik Nol karya Nawal elSaadawi. Kekerasan mengandung unsur kejahatan, kekerasan terhadap perempuan adalah segala bentuk tindakan yang dapat mengakibatkan timbulnya kesengsaraan atau penderitaan terutama bagi perempuan baik secara fisik, psikis, seksual maupun penelantaran rumah tangga termasuk ancaman, pemaksaan, atau perampasan kemerdekaan seseorang.

Apong (dalam Martha, 2003:113) menyatakan bahwa "Tindakan kekerasan terhadap perempuan yaitu setiap tindakan yang menyebabkan kerugian atau penderitaan fisik seperti pemukulan, pelecehan seksual, serta penganiaan atau psikologis terhadap perempuan." Hal ini terlihat dari tindakan kekerasan yang didapatkan oleh Firdaus dalam novel Perempuan di Titik Nol karya Nawal elSaadawi.

Berikut ini adalah aspek-aspek feminisme radikal tokoh Firdaus yang terkandung dalam novel Perempuan $d i$ Titik Nol karya Nawal el-Saadawi.

Aspek kekerasan terhadap perempuan ini tergambar dari tokoh Firdaus yang sering mengalami tindakan kekerasan dari orang-orang disekitarnya. kekerasan Fisik dialami oleh Firdaus yang dilakukan oleh ayah, ibu, Bayoumi, serta Marzouk. Kekerasa fisik juga dilakukan oleh istri paman Firdaus terhadap pembantunya. Kekerasan psikis dialami oleh Firdaus yang dilakukan ayah dan ibunya, Bayoumi, dan Di'aa. Kekerasan psikis juga dialami Firdaus, saat mencoba kabur dari rumah pamannya, kekerasan juga dialami oleh Firdaus yang dilakukan oleh Muhammadin, paman Firdaus, Bayoumi, serta seorang polisi, selain itu kekerasan dalam rumah tangga dilakukan oleh ayah Firdaus, terhadap istrinya dan juga dilakukan oleh Syekh Mahmoud terhadap Firdaus. Pada aspek kekerasan terhadap perempuan, terdapat 15 kutipan.

Aspek ekploitasi perempuan tergambar dari tokoh Firdaus ditandai dengan eksploitasi tubuh Firdaus yang dilakukan oleh Bayoumi, Ibrahim, dan laki-laki yang bertemu dengan Firdaus saat kabur dari tempat Syarifa yang sudah menjadikannya sebagai seorang pelacur. Eksploitasi ekonomi perempuan juga dialami Firdaus yang dilakukan oleh istri paman Firdaus, Syarifa, dan Marzouk. Eksploitasi ekonomi perempuan juga dilakukan oleh ayah Firdaus terhadap anak-anak perempuannya. Pada aspek ekploitasi perempuan, terdapat 8 kutipan.

Aspek peran perempuan juga tergambar dsri tokoh Firdaus untuk mengakhiri dominasi laki-laki, dengan cara kabur dari rumah pamannya, kabur dari rumah suaminya, kabur dari rumah Bayoumi, serta menghindari laki-laki yang ingin mendekatinya, dan membunuh Marzouk, yang mencoba menjadikan Firdaus sebagai pelacur. Kegagalan perempuan terjadi akibat perempuan yang tidak berani melakukan perlawanan terhadap laki-laki yang mencoba mendominasi akibat budaya patriaki. Kegagalan perempuan juga terjadi akibat perempuan yang berbuat hina terhadap kaumnya sendiri dengan menjerumuskan perempuan ke dalam pelacuran. Pada Aspek peran perempuan, terdapat 9 kutipan.

\section{Pembahasan Aspek Kekerasan Fisik Terhadap Perempuan}

(1.1) Maka pada suatu hari saya bertanya kepada ibu tentang dia. Apa sebabnya ibu 
melahirkan saya tampa seorang ayah? Mula-mula ia memukul saya kemudian ia membawa wanita yang membawa sebilah pisau kecil atau barangkali pisau cukur. Mereka memotong secuil daging diantara kedua paha saya. (hlm. 18).

Kutipan (1.1) di atas termasuk ke dalam aspek kekerasan terhadap perempuan, karena ibu Firdaus memukul Firdaus ketika hendak bertanya tentang jati dirinya. Firdaus tidak memperoleh jawaban yang jelas, tetapi justru dipukul ibunya. Ibu Firdaus melukai sebagian tubuh Firdaus dengan menyuruh seorang wanita membawa sebilah pisau kecil dan memotong secuil daging diantara kedua paha Firdaus tampa menjelaskan terlebih dahulu kenapa ia melakukannya.

\section{Pembahasan Aspek Ekploitasi Perempuan}

Eksploitasi merupakan salah satu aspek feminisme radikal yang terdapat dalam novel Perempuan di Titik Nol karya Nawal el-Saadawi. Ekploitasi perempuan merupakan tindakan dengan atau tampa persetujuan korban yang meliputi pelacuran, kerja atau pelayanan paksa, perbudakan, penindasan, pemerasan, pemanfaatan fisik, seksual, organ reproduksi, atau secara melawan hukum memindahkan atau menstransplantasi organ atau jaringan tubuh, atau memanfaatkan tenaga atau kemampuan seseorang oleh pihak lain untuk mendapatkan keuntungan baik materiil maupun imaateril. Kajian tersebut sesuai dengan pendapat Fakih, (2001:18) bahwa "Eksploitasi perempuan merupakan tindakan dengan atau tampa persetujuan korban yang meliputi pelacuran, kerja atau pelayanan paksa, perbuatan atau praktik serupa penindasan, pemerasan, pemanfaatan fisik, atau menstransplantasi organ atau jaringan tubuh perempuan."

Salah satu bentuk gambaran aspek eksploitasi perempuan terdapat dalam kutipan novel Perempuan di Titik Nol karya Nawal el-Saadawi.

(2.1) Hangat benar di dalam rumahnya, dan dia menolong saya menanggalkan baju, membukakan sepatu saya yang penuh lumpur, lalu mamandikan saya dengan air hangat dan sabun. Kemudian dia mendukung saya ke atas tempat tidur. Saya menutup mata ketika merasakan berat badannya menekan dada dan perut saya, dan jari-jarinya bergerak meraba tubuh saya. (hlm.91).

Kutipan (2.1) di atas termasuk ke dalam asek eksploitasi perempuan, karena menunjukkan terjadinya eksploitasi tubuh Firdaus yang dilakukan oleh seorang lakulaki yang bertemu pada saat Firdaus pergi dari tempat Syarifa. Laki-laki ini memperlakukan Firdaus dengan sopan dan baik. Seorang laki-laki tidak dikenal membawa Firdaus kerumahnya. Dia menolong Firdaus dari rasa kedinginan, namun yang dilakukannya sama dengan laki-laki lain. Memanfaatkan tubuh Firdaus untuk kepuasan seksualnya. Firdaus mengalami ekploitasi tubuh dari laki-laki tersebut. Tubuh Firdaus dimanfaatkan untuk kepuasan dirinya, tampa memikirkan status hubungan mereka.

\section{Pembahasan Aspek Peran Perempuan}

Perempuan sebenarnya mempunyai peran yang sama degan laki-laki dalam kehiupan sosial, politik, ekonomi, serta kultur. Ketika perempuan sudah mempunyai hak yang sama dengan laki- 
laki, maka perempuan dapat keluar dari dominasi laki-laki. Perempuan harus benar-benar berilmu dan mempersiapkan diri sesempurna mungkin untuk keluar dari dominasi laki-laki.

Peran perempuan dalam novel Perempuan di Titik Nol karya Nawal el-Saadawi meliputi perlawanan perempuan dan kegagalan perempuan. Peran perempuan yang dimaksud seperti tergambar dalam kutipan berikut.

\section{(3.1) Saya berjalan sepanjang jalan, seperti yang telah berkali-kali saya lakukan sebelumnya, tetapi kali ini rasanya agak berlainan, karena saya tidak punya tujuan tertentu. Saya tidak punya tujuan kearah mana saya melangkah. Ketika saya memandang ke arah jalan, seakan-akan saya melihatnya untuk pertama kali. Suatu dunia baru telah terbuka dihadapan mata saya, suatu dunia bagi saya yang belum pernah ada. (hlm.57).}

Kutipan (3.1) di atas termasuk ke dalam asek peran perempuan karena menunjukkan perlawanan perempuan yang dilakukan Firdaus dengan kabur dari rumah pamannya meskipun tampa tujuan yang jelas. Firdaus tidak ingin menikah dengan laki-laki pilihan istri pamannya. Meskipun demikian, Firdaus merasa menemukan kebebasan saat berada di jalan, dia merasakan suatu kebebasan yang tidak dia rasakan sebelumnya. Saat kabur dari rumah pamannya, Firdaus merasa kembali mempunyai tujuan hidup yaitu hidup bebas. Firdaus merasakan dunia baru di luar, karena selama ini dia terkurung di rumah pamannya. Di rumah pamannya Firdaus hanya melihat orangorang yang tidak menyayanginya. Selama hidup Firdaus tidak pernah melihat dunia luar. Dunia yang penuh keindahan, serta kebebasan sejati.

\section{SIMPULAN DAN SARAN}

Berdasarkan hasil penelitian dan pembahasan, dapat disimpulkan bahwa dalam novel Perempuan Di Titik Nol karya Nawal el-Saadawi, terkandung feminisme radikal tokoh Firdaus dalam bentuk kekerasan terhadap perempuan 15 kutipan; eksploitasi perempuan 8 kutipan; dan peran perempuan 9 kutipan. Jumlah kutipan aspek feminisme radikal dalam novel Perempuan Di Titik Nol berjumlah 35 kutipan. Berdasarkan paparan tersebut dapat disimpulkan bahwa aspek feminisme radikal tokoh Firdaus yang paling mendominasi adalah aspek kekerasan terhadap perempuan, yaitu sebanyak 15 kutipan.

\section{DAFTAR PUSTAKA}

Arikunto, S. (2010). Metode Penelitian. Jakarta: Rineka cipta.

Fakih, M. (2001). Analisis Gender dan Transpormasi Sosial. Yogyakarta: Pustaka Pelajar.

Siswantoro, Wahyuni. (2018). Pengantar Teori Sastra. Jakarta: PT Garasindo

Siswantoro. (2010). Metode Penelitian Sastra. Surakarta : Pusat Pelajar.

Meolong, 2(010). Metode Penelitian Kualitatif. Bandung: PT Remaja Rosda Karya.

Martha. (2003) .Perempuan, Kekerasan, dan Hukum. Yogyakarta. UII Press

http://www.jlls.org/vol9no2/31-44.pdf http://www.luarkampus.com/2011/09/degr adasi-moral-vs-pendidikan-karakter$\underline{\mathrm{html}}$

Rafiek, A. (2012). Ilmu Sosial dan Budaya Dasar. Yogyakarta: Aswaja Presindo. 